\title{
PREVALENCE OF ORAL HEALTH IN THE AREA OF TUZLA CITY
}

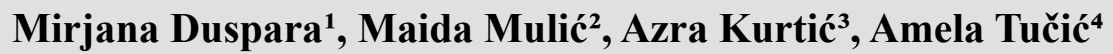

(C) 2019 by Acta Medica Saliniana ISSN 0350-364X

DOI: $10.5457 / 495$

Mirjana Duspara, Maida Mulić, Azra Kurtić, Amela Tučić

\section{Afiliations:}

1Public Health Scientific Institution Medical center ,, Dr Mustafa Šehović“ Tuzla, 2Tuzla University, Faculty of Medicine - Social Medicine Department, 3Tuzla University, Faculty of Medicine, 4 Specialist Dental Practice dr Amela Tučić

Received:

12.02.2019.

Accepted:

01.11.2019.

Corresponding author:

Mirjana Duspara

Email: duspara.mirjana@gmail.com>

Funding: none

Competing interests: none

\section{ABSTRACT}

Caries is the most widespread oral desease of all age groups, the main oral-health problem as well as the leading cause of teeth loss. Bosnia and Herzegovina has a huge prevalence of caries patients in comparison with a significant decline in developed countries. Postwar state period, inadequate nutrition and neglected care of oral health have reflected on oral health of children in Tuzla City.

Aim: to determine prevalence of oral health of children of different age groups in the area of Tuzla City.

Methods: physical checkup and education have encompassed 5452 children of different age groups in the period from 2011 to 2017 (5098 of six- year- olds, 114 twelveyear-olds, 120 fifteen-year-olds and 120 eighteen-year-olds). Physical checkups were done in dental practices of Public Health Scientific Institution (hereinafter PHSI) Medical Center Tuzla, children's department, with a dental probe and mirror. CES (caries, extraction, sealed teeth- permanent) and CES (caries, extraction, sealed teethdairy) were calculated on the basis of 100 checkups. During the same period there were educations for pregnant women in the first and last quarter of pregnancy organized within the school for pregnant women of the Women Dispensary of PHSI Medical Center Tuzla.

Outcomes: the research determined the value of CES index of diary teeth for six-yearolds $(6,41)$ in 2011 that was decreased in $2017(5,19)$ what indicates a good effect of educative lectures. CES index of tvelwe-year-olds in 2017 was 3,2. The research proved that high school children (15-year-olds) have a high CES index $(8,3)$ in year 2013/14 and the same group of examinees as graduates (18-year-olds) in 2016/17 had CES index of 7,73 .

Conclusion: CES of the examinees had very high values, far from the aim of the World Health Organization $(1,5)$.

Programs and activities of oral health promotion of the Dental Service of PHSI Medical Center Tuzla have made changes, warned of the importance of preventive action as well as triggered revitalization of preventive detal protection for preschool and school population of Tuzla City.

Key words: caries, CES/ces index, physical checkup, education, Tuzla.

\section{INTRODUCTION}

Oral health represents healts of hard and soft tooth tissue including mucous membrane of the mouth, tongue and mucous membrane of the face. Good oral health is a sign of a healthy and vital human organism because any change in the oral cavity is a sign of a disease. Caries and its complications as wel as diseases of soft tissues have a negative impact on the whole organism (focal changes). Acording to the WHO definition, teeth caries is a local local post-eruptive pathological process of exogenous origin, progressive flow, irreversible nature and insufficiently clarified etiology (1). It affects the hard teeth tissue, causes its demineralization due to the action of acid-producing bacteria which consequently results in a loss of teeth. Previous researches have shown that caries can be prevented and controlled by using preventive measures with reliable epidemiological data on its distribution (2) that does not exist in Bosnia and Herzegovina. Caries prevalence in the World is declining in developed countries due to a better organization of dental protection, availability of fluoride preparations, and improvement of oral hygiene as well as better consciousness on the occurrence 
of caries (3). Since 1938, CES index has been relevant in following of distribution trends of caries used by WHO in its assessment of oral health and indicates the intensity, i.e. frequency of caries (4). Economic crisis and political situation in Bosnia and Herzegovina, the long-lasting lack of preventive procedures and the promotion of oral health are the reasons why Bosnia and Herzegovina belongs to countries with a high CES index. Abolishing of school practices in primary and secondary schools has worsened the health of children's teeth since they have stopped implementing preventive measures, systemic care for the health of children's teeth has ceased.

Multiple causes of caries represent significant requirements for health protection, especially for preventive protection of oral health.

It is important that there is no possibility to put caries under control only by recovery, it is necessary to use all the available models of prevention in a properly planned preventive program, start the prevention from the earliest age of teeth growth, pre and post eruptive mineralization and maturation, i.e. from pregnant women to adolescent age of children (5). Six-year olds were the target group of this research (mostly diary dentition) and twelve-year-olds (mostly permanent dentition) were chosen as a global age group used by the WHO in monitoring of disease trends in the world. From the experience of West European countries, it has been noted that schools are an important platform for the control of oral health of children and relevant indicators of oral health promotion (6). Examples of the previously mentioned are Scandinavian countries that have a long-lasting practice of dental protection for school children and youth up to 18 years old. Bosnia and Herzegovina and Tuzla City are far from the goal set by the WHO for the year 2020 as a part of Health 21 Politics for Europe.

\section{AIM}

to determine prevalence of oral health of children of different age groups in the area of Tuzla Municipality

\section{METHODS AND WORKFLOW}

The basic premise of this mission during physical checkups was that any individual is obliged to take care of his/her health and the dentists have the task to support them. 5098 physical checkups of six-yearolds was done in the period from 2011 to 2017 in dental practices of PHSI, Medical Canter Tuzla as well as 114 physical checkups of twelve-year-olds, 120 of fifteen and 120 of eighteen-year-olds. Physical checkup of six-year-olds was done in 2011 and then repeated when they were twelve-year-olds (114 in total) in 2017. Physical checkup of 120 fifteen-year-olds pupils in first grade of Behrambeg's Madrasah was done in the school 2013/14 year and control checkup of the same group in 2016/17 when they were eighteen-year-olds in fourth grade of secondary school. Educational lectures for 3651 twelve-year- olds were done in elementary schools in the municipality of Tuzla. Continuous educations and workshops have been held in the first grade of the Behrambeg's Madrasah since 2009 on the topic of prevention and importance of oral health, proper nutrition of adolescents and teeth brushing techniques. The permission for implementation of the Program "Healthy teeth for a beautiful smile" was given by the Ministry of Education, Sports and Culture.

Educational lectures, presentations in nurseries, elementary and secondary schools were delivered by the dentists with use of computers and promotion materials, presentations on proper brushing of teeth on models with active participation of the pupils. There were nine lectures for pregnant women in the School for Pregnant Women of the Women Dispensary of PHSI Medical Center Tuzla.

\section{OUTCOMES}

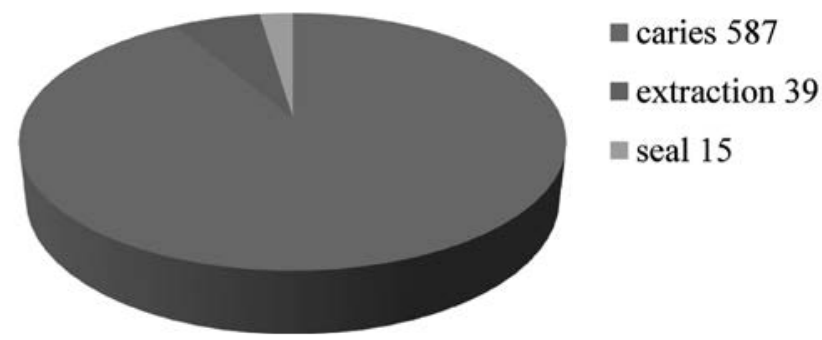

Chart 1. CES index of six-year-olds pupils in the first grade of elementary school in $2011-6,41$.

CES index of the pupils who started the first grade of elementary school in 2011 was 6, 41 with 587 teeth with caries, 39 extracted teeth and only 15 sealed diary teeth (random sample of 100 children). Researches of Ruhayaa and associates indicated the value of CES index of six-year-olds in Malaysia of 11, 1 (16).

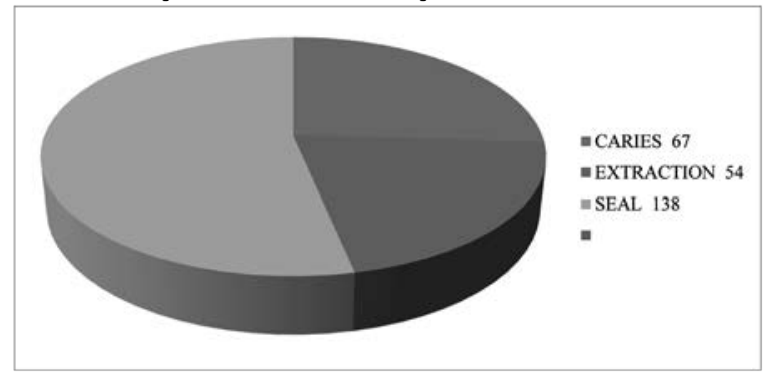

Chart 2. CES index of pupils of the sixth grade in 2017 $(3,2)$

It was noticed that twelve-year-olds had CES index of 3, 2 (it was 6,41 when they were 6 years old) of which 67 with caries, 54 extracted and 138 sealed. Analysis of other researches indicated the following: CES index of twelve-year-olds in Denmark- o, 6; Sweden o, 8 and Norway 1,7. CES index of twelve-year-olds in Mexico was 3, 24, (11), Philippines 2, 4 (12), Spain 1, 07 (13) and Nicaragua 0,65 (14). 


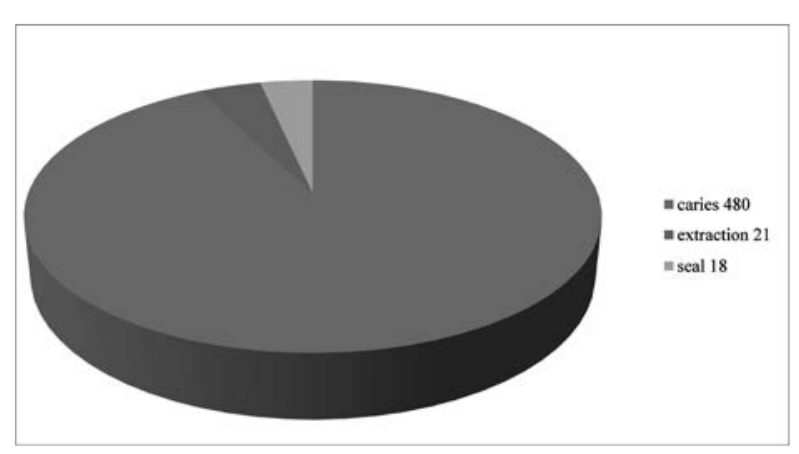

Chart 3. CES index of first grade pupils in elementary school $2017(5,19)$

CES index of pupils of the first grade in 2017 was 5 , 19 with 480 teeth with caries, 21 extracted teeth, and only 18 sealed teeth (random sample of 100 elementary school pupils in the area of Tuzla City). Efficiency of a continuous education was pointed out by decrease of CES index.

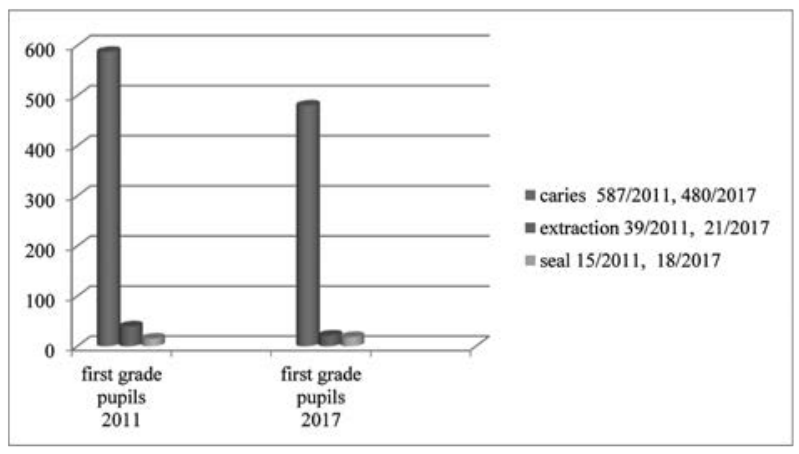

Chart 4. Comparison of CES index of six- year-olds in $2011 / 17$

CES index of six- year-olds in 2011 was 6,41 with 587 teeth with caries, 39 extracted teeth and 15 sealed teeth. CES index of six- year-olds in 2017 was 5, 9 with 480 teeth with caries, 21 extracted and 18 sealed teeth. Analysis of the data confirmed improvement in decrease of CES index.

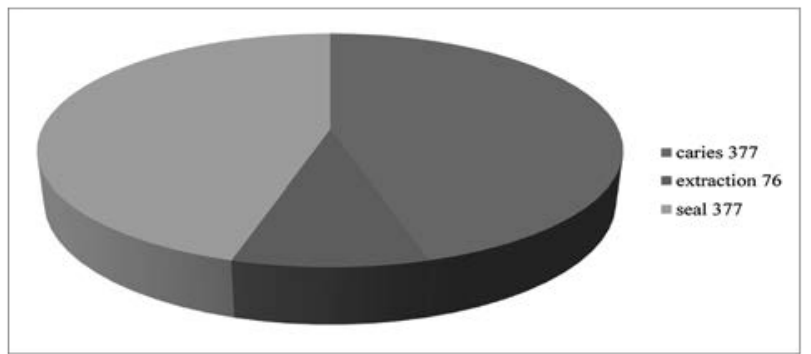

Chart 5. CES index $(8,3)$ of pupils in first grade of secondary school -fifteen years old in 2013/14

CES index of first grade pupils of first grade of secondary school in school year 2013/2014 is 8,3 (377 teeth with caries, 76 extracted and 377 sealed) shows the same number of extracted and sealed teeth. Von der Fehr (8) showed in his research that in Nordic countries CES of fifteen-year-olds is $3,1$.

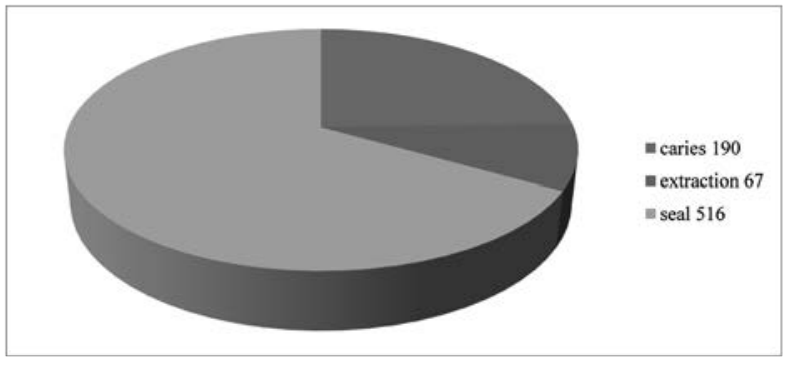

Chart 6. Control CES index of 18 years old pupils in 2016/17 (7,73)

Control CES index was done in April of the academic year 2016/17 for the same groups of examinees and it was 7,73 . The same age group had less teeth with caries (only 190 in comparison to 377), and also more sealed teeth ( 516 in comparison to 377). In Hungary, CES index value of eighteen-yera-olds was 7,6 (19).

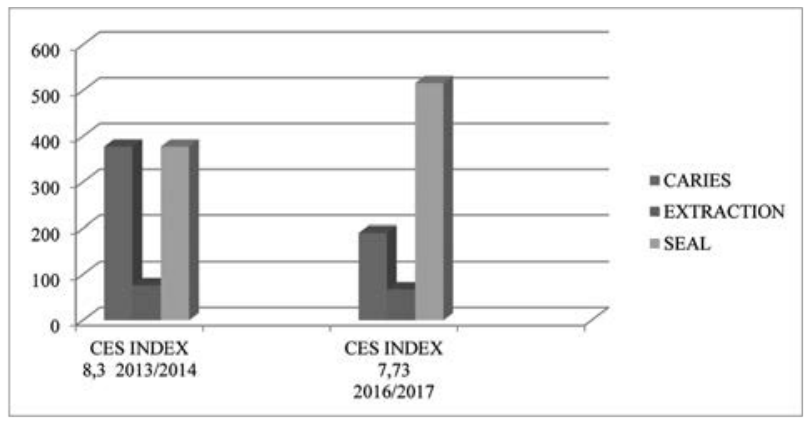

Chart 7. Comparison of CES index of the same generation of secondary school pupils in 2013/14 and 2016/17

Comparing the outcomes it was noticed that the same age group had less teeth with caries and more sealed teeth as well as the response to the scheduled appointments was not $100 \%$. CES index was decreased to 7,73 .

\section{DISCUSSION}

According to the WHO data, $60-90 \%$ of school children and the vast majority of adults have had caries what which points to its prevalence and a public health problem that appears in most industrialized countries (7). Von der Fehr (8) showed in his research that in Nordic countries CES of fifteen-year-olds is 3, 1 and 5,3 for eighteen-year-olds. The same age groups in Czech Republic have the values of 5, o (9) and 6,2 (10).

Cooperation of Dental service and management of Behrambeg's Madrasah has been ongoing since 2009. Continuously, once a year, pupils of the first grade of the above mentioned school have education, physical checkup and teeth treatment in the Dental Service, School Department.

CES index of first grade students in the school year 2013/14 was 8, 3 (377 teeth with caries, 76 extracted and 377 sealed) and the same number of teeth with 
caries and sealed teeth was noticed. The expectations were different due to a huge interest of the students during lectures and workshops. Control CES index of the same group of examinees was done in April (school year 2016/17) and it was 7, 73 what represents defeating data. Comparing the results, the same age group had fewer teeth with caries (only 190 comparing to 377) and more sealed teeth ( 516 comparing to 377 ). A higher adherence of students and a smaller value of control CES were expected as because during the physical checkups the better oral hygiene of students in the fourth grade was noticed. The high school students that were subject to this research, were living in the boarding school conditions with very strict hygiene discipline, quality nutrition including three meals, the same life organization during schooling, habits and tradition of which the school management was taking care, on students' oral health and heath in general. Due to such regulated system of life, the expectations were much higher. CES index of twelve-year-olds in Tuzla City, according to the research, was 3, 2. Comparison to other countries shows that the value of CES index in the same population group was the highest in Mexico (11) 3, 24, Philippines (12) 2, 4, Spain (13) 1, 07, and the lowest in Nicaragua (14) o, 65. Care on dental health in Scandinavian countries resulted in low values of CES index of twelve-year-olds in Denmark (o, 6), Sweden $(0,8)$ and Norway $(1,7)$. The WHO and WDF have set the goal for 2000 that the twelve year old children should not have more than three teeth with caries and three sealed teeth (15). Researches of Ruhayaa and associates pointed out the CES index of six-year-olds in Malaysia (16) of 11, 1 while in Tuzla City it was 6, 41 in 2011 and 5, 19 in 2017. The results show that the CES index decreased and education in nurseries and the physical checkup before the elementary school had an effect on prevention of caries. Ivankovic and associates have done research in four regions in Bosnia and Herzegovina after the war and it showed the CES index of six- year-olds of 4,9 in 1997 (86\% of children had caries) and 6, 2 of twelve-year-olds (94\% of children had caries) (17). The Study done in Sarajevo in 1999 showed that $89 \%$ of six- year-olds had caries as well as $96,98 \%$ of twelve-year-olds (18). The tendency of declining caries prevalence was also noticed in Hungary where the results of the research showed the CES value of 7.6 in eighteen-year-olds (19).

Monitoring the caries prevalence in developed countries Kunzel has pointed out dividing European countries into two regions: West European Region (countries with low risk) with average CES index of 1 , 7 and $40 \%$ of twenty-year-olds with no caries and East Europe Region (countries with high risk) with average CES index of 4,1 and $10 \%$ of twenty-year-olds with no caries (20).

The available data from the WHO data base on oral health show high values of CES index in: Bosnia and Herzegovina 4, 2, Albania 3, 7, FRY Macedonia 3, 5 , Poland 3, 2 and Bulgaria 3, 1 (21). In 2004, CEC index for twelve-year-olds in Bosnia and Herzegovina was 4, 16 in accordance with the Research of Muratbegovic and associates (22). It is significant that in Zagreb, in the period from 2009 to 2010 , CES index of twelveyear-olds was $4,8(23)$. In the research done with children with developmental difficulties and healthy children at the age of 3 to 17 years in Rijeka, average CES was 6, 39 for children with developmental difficulties and 4, 76 for the healthy boys and girls (24). Analysing the research outcomes, a huge difference in value of CES that should be strategically solved was noticed. Continuous educations and presentations have confirmed improvement in maintenance and preservation of permanent teeth in comparison to diary teeth, a decreased number of extractions and an increased number of sealed teeth.

\section{CONCLUSION}

As caries is a public health issue, so it is necessary to have a unique data base of CES indexes in Bosnia and Herzegovina. CES index of dairy and permanent teeth is the indicator which objectives and plans should be included into the Preventive Program of Oral Health. Programs and activities of oral health promotion of the Dental Service have provided changes, warned on the importance of preventive actions and encouraged revitalization of preventive dental protection of preschool and school population of Tuzla City. It is possible to achieve the basic objectives of the oral health protection program in nursery by joint action of all the participants: parents, medical and pedagogical staff. If the children adopt prevention and responsibility towards their health it will be easier for them later on to adopt other preventive activities, to be more responsible members of the community and in that way decrease their personal and general expenditures in regards to health. National programs of oral health prevention, unique data base, proper planning, prevention and education have been the fundament of the current as well as the future functioning of Dental Service. This research set the obligatory task for the future that is reflected in a daily audit in scope of the persistence of the realization of the ideal of medicine, and that is that the illness must be prevented, i.e. the children born today can be one day twenty-year-olds with healthy teeth.

\section{REFERENCES}

1. WHO Expert Committee on Dental Health, World Health Organization. Standardization of reporting of dental diseases and conditions: report of an expert committee on dental health (internet).Geneva: WORLD Health Organization; 1962 (cited 2015 August 21). Available from; http;//apps. who.int/iris/bit 
stream/10665/38150/1/WHO_TRS_242.pdf.

2. Abhishek M. Comprehensive review of caries assessment systems developed over the last decade. RSBO 2012;9(3):316-21.

3. Frazao. Epidemiology of dental caries; when structure and context matter. Braz Oral Res. 2012; 26(1);108-114.

4. Klein H, Palmer C. Studies on dental caries vs. familial resemblance in the caries experience of siblings. Public Health Rep. 1938;53:1353-64.

5. Krsnik R. Mogućnosti kontrole karijesa provedbom preventivnog programa u vrtićima. Zagreb; Sveučilište u Zagrebu,1994.

6. Petersen PE. Changing oral health profiles of children in Central and Eastern Europe:challenges for the 21st century. World Health Organization 2015

7. Petersen PE,Lennon MA. Efective use of fluoridesforthepreventionofdentalcariesinthe 21st century:the WHO aproach.Community Dent OralEpidemiol.2004;32:319-21

8. von der Fehr FR. Caries prevalence in the Nordic countries. Int Dent J 1994; 44(4 Suppl 1): 371-8.

9. Krejsa O, Broukal Z, Mrklas O. Oral health and treatment need in children and adolescent aged 5, 12, and 15 years in Czech Republic 1998. Community Dental Health 2000; 17: 203-4.

10. Krejsa O, Mrklas L, BroukalZ. Caries experience of 18-year-old recruits in the Czech Republic in 1995. Caries Res 1996; 30:302.

11. Villalobos-Rodelo JJ, Medina-Solís CE, MolinaFrechero N, Vallejos-Sánchez AA, PontigoLoyola AP, Espinoza-Beltrán JL. Dental caries in schoolchildren aged 6-12 years in Navolato, Sinaloa, México: experience, prevalence, severity and treatment needs. Biomedica 2006; 26(2): 224-33.

12. Yabao RN, Duante CA, Velandria FV, Lucas $M$, Kassu A, Nakamori M, et al. Prevalence of dental caries and sugar consumption among 6-12-y-old schoolchildren in La Trinidad, Benguet, Philippines. Eur J Clin Nutr 2005; 59(12): 1429-38.

13. Almerich Silla JM, Montiel Company JM. Oral health survey of the child population in the Valencia Region of Spain (2004). Med Oral Patol Oral Cir Bucal 2006; 11(4): E369-81.

14. Herrera MS, Medina-Solis CE, Maupomé G. Prevalence of dental caries in 6-12-year-old schoolchildren in Leon, Nicaragua. Gac Sanit 2005; 19(4): 302-6.

15. World Dental Federation FDI World Health Organization WHO: global goals for oral health in the year 2000. FDI Int Dent J.1982;32:74-7.

16. Ruhayaa $H$, Jaafara $N$, Jamaluddina $M$, Ismaile AR, et al. Nutritional status and early childhood caries among preschool children in Pasir Mas, Kelantan, Malaysia. Arch Orofac
Sci. 2012;7(2):56-62.

17. Ivanković A, Lukić IK, Ivanković Z, Rodić A, Vukić I, Šimić A. Dental caries in postwar Bosnia and Herzegovina. Community Dent Oral Epidemiol 2003;31:100-104i

18. Kobašlija S, Maglajić N, Huseinbgović-Čengić A, Tahmiščija H. Prevalencija karijesa u djece u Sarajevu. Acta Stomatoel Croat 2000;34(1):8385

19. Szoke J, Petersen PE. Evidence for dental caries decline among children in an East European country (Hungary). Community Dent Oral Epidemiol. 2000; 28(2):155-16o.

20. Kunzel W.Zur Konversion dr epidemiologischen Zucker/caries relation i Europe. Oralpprophxilaxe.2001;23:66-70.

21. World Health Organization;2015 Available from: http//www.mah.se/CAPP/CountryHealth-Profles/EURO/Croatia/Oral-Diseases/ DentalCaries/

22. Muratbegović A, Marković N, Kobašlija S, Zukanović A. Indeksi oralnog zdravlja i hipomineralizacija kutnjaka i sjekutića kod bosanske djece $\mathrm{u}$ dobi od 12 godina. Acta Stomatol Croat 2008;42(2):155-163.

23. Dukić W,Delija B, Lulić Dukić O. Caries prevalence among school-children in Zagreb, Croatia. Croat Med J. 2011; 52:665-71.

24. Ivančić Jokić $N$, Majstorović $M$, Bakarčić D. Katalinić A, Szirovicza 1. Dental caries in disabled children. Coll Antropol. 2007;31(1):321-4. 